\title{
Are Canadian Banks Ready for Basel III?
}

\author{
Imad Kutum $^{1} \&$ Khaled Hussainey ${ }^{2}$ \\ ${ }^{1}$ Kutum \& Associates Inc, A1-5659 McAdam Road, Mississauga, ON, L4Z 1N9, Canada \\ ${ }^{2}$ Professor of Accounting, Plymouth Graduate School of Management \& Plymouth, Business School (Faculty of \\ Business), Room 205, Cookworthy Building, Drake Circus, Plymouth, Devon, PL4 8AA, UK \\ Correspondence: Imad Kutum, Kutum \& Associates Inc, A1-5659 McAdam Road, Mississauga, ON, L4Z 1N9, \\ Canada. Tel: 1-905-330-6826. E-mail: imad@kutum.com
}

Received: August 4, 2014

Accepted: August 13, 2014

Online Published: August 15, 2014

doi:10.5430/afr.v3n3p159

URL: http://dx.doi.org/10.5430/afr.v3n3p159

\begin{abstract}
The purpose of this study is to analyze and test the current liquidity coverage ratio of Canadian banks', and draw conclusions about the readiness of Canadian banks to meet Basel III regulations.

Liquidity coverage ratios for six major Canadian banks were calculated using the liquid assets and liabilities listed on their balance sheets from 2009 to 2013. The actual assets that meet Basel III requirements could not be acquired, as this is private information that does not have to be released until 2015.

Five of the six major Canadian banks that were examined are likely to be able to meet Basel III requirements in 2015. While some of the banks are already on their way to achieving full 2019 compliance, one of the banks is only barely meeting the 2015 requirements, raising the question of whether it will be able to meet and maintain Basel III liquidity requirements.

The limitation of this study is that the liquidity coverage ratio formula used in Basel III could not be calculated, as the specific assets that meet Basel III requirements could not be obtained for the Canadian banks. The implication is that Canadian regulators need to focus attention on those banks that have been shown to be potentially unable to meet Basel III liquidity requirements.

The value of this study is based in part on the lack of similar studies conducted on Canadian banks. This is one of the few studies of this nature not conducted on banks in the United States or the United Kingdom.
\end{abstract}

Keywords: Liquidity coverage ratio, Canadian banks, Basel III, Canada, Financial crisis

\section{Introduction}

The 2008 financial crisis has largely been blamed on the risks taken by banks related to their investments in the mortgage and derivatives markets that resulted in a lack of liquidity (Jordan, Branch, McQuay, Cooper \& Smith, 2013). Major financial institutions such as Bear Stearns, Northern Rock and AIG, which were major sources of loans and funding for individuals and banks, not only lacked the liquidity to be able to make loans, but actually lacked the funds needed to remain financially viable (Bessis, 2011). The resulting need for countries such as the United States (US) and the United Kingdom (UK) to provide massive bailouts to banks caused the issue of bank liquidity to become a major issue (Asongu, 2013). The Basel Committee on Banking Supervision implemented new guidelines, known as Basel III, to increase bank liquidity as a way of reducing the threat for a future financial crisis such as the one that occurred in 2008 (Gomes \& Khan, 2011).

Much of the academic literature about bank liquidity and Basel III has been focused on financial institutions in the US and the UK. Little attention has been given to the issue of bank liquidity for Canadian banks, or their ability to meet liquidity coverage ratios under the Basel III guidelines. The purpose of this study is to analyze and test the current Canadian bank liquidity coverage ratio in order to draw conclusions about the readiness of Canadian banks to meet Basel III regulations. The motivation for carrying out this investigation is to better understand the liquidity issues and readiness of Canadian banks to meet Basel III requirements by using data from Canadian banks themselves, rather than making inferences from data collected from banks in the US or the UK. The importance of this study is that the results of the data analysis performed can be used by researchers, practitioners, and government officials to determine what further actions may be needed in Canada in order to ensure that Canadian bank liquidity will meet the increasing liquidity coverage ratios mandated under Basel III requirements. 
The key findings of this study are that most of the larger Canadian banks are ready to meet Basel III liquidity coverage ratio requirements. In fact, some of the large Canadian banks are almost to the point of being able to meet the full $100 \%$ liquidity coverage ratio, which does not take effect until 2019 . Unfortunately, there is one large Canadian bank that shows potential signs of trouble when it comes to whether it will be able to meet the earlier 2015 liquidity coverage ratio requirement, as well as whether it will be able to meet the increases in liquidity coverage in subsequent years.

This paper begins with an examination of the relevant literature to this study, including information about liquidity ratios and Basel III requirements, bank liquidity in general, and the conceptual framework of the liquidity coverage ratio. Next, an explanation of the methodology used to carry out this investigation is provided. Then, an explanation of the results of the analysis performed on the data collected for this study is outlined, followed by the conclusions drawn from the results of this study.

\section{Literature review}

\subsection{Liquidity ratios and Basel III}

The International Framework for Liquidity Risk Measurement, Standards and Monitoring, better known as Basel III, was published in December 2010 as a means of addressing the concerns of bank liquidity that arose with the financial crisis that began in 2008 (Gomes \& Khan, 2011). One of the most important parts of the Basel III requirements is the use of liquidity ratios to measure the assets that banks hold in relation to their liabilities (Ramona, 2013). Liquidity ratios provide a quantitative measure to creditors and investors about the ability of a business or institution to cover its liabilities. In the case of banks, the use of liquidity ratios under Basel III is viewed as a means of ensuring that those banks have enough high-quality assets to cover the risks that they take when loaning money to individuals and investors (Gomes \& Khan, 2011). Monitoring the level of assets to the level of liabilities taken on by banks is meant to ensure that banks do not take on the high levels of risks they did during the early 2000 s when they engaged in the sale of large amounts of sub-prime mortgages and other high-risk derivative investments that led to the financial crisis in 2008 (Vasile \& Nitescu, 2012).

One of the problems that arose in the years leading up to the financial crisis is that banks invested heavily in long-term liabilities, such as mortgages, without considering their abilities to meet short-term obligations. As banks invest in long-term liabilities such as mortgage loans, a problem of short-term liquidity can arise. If a bank suddenly finds that depositors withdraw large amounts of funds, they may not have the short-term liquidity to maintain operations, because turning a long-term mortgage liability into short-term capital is often difficult (Hartlage, 2012). The goal of Basel III requirements is to ensure that banks can withstand a 30-day financial shock by having enough liquid assets that can be used to maintain operations during such an event (Gromova-Schneider \& Niziolek, 2011). It is believed that with the Basel III requirements, banks will have to be much more aware of the amount of long-term liabilities they face, and will be forced to consider their own liquidity as a basis for making lending and investment decisions (Bank for International Settlements, 2013).

\subsection{Liquidity risk}

In order to discuss the concept of liquidity risk, it is necessary to define what is meant by the term "liquidity". It has been noted that liquidity is a term that is often easier to identify than to actually define, because it can be defined differently in different contexts (Clerc, 2008). For example, market liquidity is the trading of a particular amount of assets or securities in a market without a significant impact on their price (Wu \& Hong, 2012). Market liquidity increases when the threat of receiving a reduced price for a volume of assets is present within a market because investors sell the assets, which results in increased liquidity. However, instrument liquidity is the level of risk associated with being able to trade financial instruments without a loss of value (Brunnermeier \& Pedersen, 2009). An example of instrument risk might be securitized mortgages and the threat of taking a loss on the sale of securitized mortgages. In comparison, liquidity risk for banks is the ability of banks to raise funds to meet obligations without incurring high costs or losses (Jasevičiené, Jasiene, Martinavicius, Jaseviciene, \& Krivkiene, 2012; Ismal, 2010).

Liquidity risk is created as banks use short-term funds to make long-term investments, such as offering 30-year mortgage loans to customers (Ratnovski, 2013). In fact, in recent years, loan commitments have been a major source of liquidity risk for banks (Gatev, Schuermann, \& Strahan, 2007). The argument has been made that bank liquidity risk is actually associated with market and instrument risk because, as change occurs in market conditions, such as price levels of homes, which brings the threat that securitized mortgages will sell for less, the result can be increased liquidity risk for banks that have invested large amounts of their capital into mortgages (Acharya \& Schaefer, 2006). 
Customer deposits into banks is one of the mechanisms by which liquidity risk is reduced, because as larger amounts of money are placed into banks, there is a greater amount of short-term liquid assets available to cover the illiquid securities that banks purchase and the illiquid investments that banks make, such as mortgage loans (Diamond \& Rajan, 2001).

The problem that banks have faced with regards to customer deposits in recent years and particularly before the financial crisis is that the overall value of deposits has declined, in favor of investments in the stock and bond markets. At the same time, banks turned away from focusing on their fiduciary roles with customers and focused on generating revenues and profits from investments (Bergevin, Calmes \& Theoret, 2013). The combination of reduced liquid assets and the larger use of capital for illiquid investments has created the increased threat of liquidity risk for banks.

The threat of banks having high levels of liquidity risk and not properly managing liquidity risk is the reason that Basel III requirements have been released. The Basel III requirements create an international standard for bank liquidity for the first time (Gomes \& Khan, 2011). An international standard for determining acceptable bank liquidity is considered to be important to achieve and maintain a global financial stability (Ramona, 2013). Liquidity risk does not affect only those banks that are unable to properly manage their assets and liabilities; instead, liquidity risk can impact banks that are able to manage their assets and liabilities. The financial crisis that began in 2008 came to the attention of the public because of the bankruptcy of Lehman Brothers. As depositors learned about the collapse of Lehman Brothers, they rushed to remove their money from that bank and many other banks, which created liquidity problems across the entire banking sector (Hartlage, 2012).

\subsection{Bank liquidity}

While there is no recent research regarding bank liquidity in Canada, it is helpful to examine some of the recent literature about changes in bank liquidity in other countries, as well as studies in which the impact of Basel III requirements have been investigated. From these studies, it may be possible to hypothesize whether Canadian banks may be able to meet Basel III liquidity coverage ratio requirements. A study was conducted regarding changes in bank liquidity in the Bahamas and Caribbean nations from 2001 to 2012 (Jordan, Branch, McQuay, Cooper \& Smith, 2013). While the study was not conducted in relation to Basel III requirements, it can provide some valuable information about how bank liquidity in a particular part of the world has changed over the course of the past decade, including the period in which the financial crisis occurred. The data showed that liquidity had increased in many Caribbean nations. In the Bahamas, the authors of the study noted that increased liquidity was due to a decline in demand for credit, as well as increased caution in issuing loans on the part of banks because of increased delinquencies of outstanding loans.

One of the issues that has already been mentioned is the argument that market liquidity is associated with bank liquidity (Acharya \& Schaefer, 2006). Vogiazas and Alexiou (2013) investigated liquidity and the business cycle among banks in Greece using data from 2004 to 2010. The researchers found that there was a significant relationship between market conditions in the country and the liquidity of Greek banks. As market conditions worsened for the country and on a global scale, bank liquidity was harmed, and bank liquidity also declined. The importance of this research may be less about changes in liquidity in Greece and more about the way in which banks in that country have been impacted by market conditions. The authors of the study argued that banks need strong basis of capital during periods of macroeconomic growth, as well as during periods of macroeconomic decline. In this regard, the larger argument would seem to be that it is necessary to put into place rules and controls in order to ensure that banks control liquidity risk regardless of the conditions in the macroeconomy.

In a similar type of study, Sohaimi (2013) investigated liquidity risk and performance on the capital reserves of banks in Malaysia. The researchers found that there was an association between performance and liquidity risk. Specifically, the researchers found that non-performing loans were associated with periods of increased bank liquidity. While these results may not seem that surprising, they do support the idea that larger market conditions do have a relationship with bank liquidity. Further evidence for the idea of market conditions being associated with bank liquidity risk is found in a study conducted by Rafea and Rad (2014), in which the liquidity risk of a single bank branch in Iran was examined for the period of 2008 to 2012; the study revealed that bank liquidity risk changed dramatically in 2008 and 2009, but not 2011 and 2012. The reason for the increase in liquidity risk in 2008 and 2009 seemed to be the bank's focus on a specific source of deposits and banking products.

Finally, studies in which the impact of Basel III requirements has been investigated across Europe show differing results due to differences in existing banking risk across European nations. For example, Nucu (2011) investigated the potential impact of Basel III on Romanian banks, and concluded that the impact is likely to be limited. That 
limited impact is likely to be due to the way in which banks in Romania structure that funds that already results in reduced liquidity risk. However, another study, which examined the liquidity of banks in Romania, showed that the overall liquidity of Romanian banks declined to 0.81 in 2011 from 1.03 in 2007 (Maria, Andrei, Catalin \& Anamaria, 2013). However, a liquidity level of $81 \%$ in 2011 following the financial crisis does indicate that Romanian banks do indeed have a high level of liquidity even without the Basel III requirements.

Finally, Avadanei (2013) investigated bank liquidity in the Czech Republic, Poland, Romania and Croatia in relation to Basel III requirements. The researcher found that banks in the Czech Republic and Croatia were best prepared to handle shocks through low levels of liquidity risk, while banks in Romania had good levels of capital to handle shocks. The researcher explained that while banks in Poland were also likely able to handle shocks, there were some liquidity issues present.

Overall, the literature that has been reviewed regarding bank liquidity in different parts of the world seems to allow for the conclusion that the financial crisis has actually made banks better able to handle the new Basel III requirements because of the problems that have already occurred. It was the credit crisis that caused banks to have to reduce the level of liabilities on their balance sheets. In this regard, the hypothesis that can be made is that banks in Canada are likely to be ready to meet Basel III requirements because of their own actions, either voluntary or involuntary, to reduce liquidity risk in the aftermath of the financial crisis.

\section{Conceptual framework}

The conceptual framework for this study, as well as for the Basel III rules to reduce liquidity risk, is the liquidity coverage ratio. Under Basel III requirements, the liquidity coverage ratio of a bank is calculated by taking the value of high-quality liquid assets and dividing by total net cash flows over the next 30 calendar days (Bech \& Keister, 2012; van den End, 2012).

Where:

$$
L C R=\frac{H Q L A}{N C F}
$$
$\mathrm{LCR}=$
Liquidity Coverage Ratio
HQLA $=$
High Quality liquid Assets
$\mathrm{NCF}=$
Net Cash Flow Over Next 30 Days

An important part of the concept of the liquidity ratio under Basel III is what is considered to be high-quality liquid assets. The assets that are considered to be high quality and liquid are those which can easily and immediately convert into cash with little or no change in their values (Bank for International Settlements, 2013).

The minimum liquidity ratio required under Basel III begins at $60 \%$ in 2015 and increases to $100 \%$ in 2019 . Table 1 shows the minimum required liquidity coverage ratio for each year (Bank for International Settlements, 2013).

Table 1. Minimum required liquid coverage ratio

$2015 \quad 2016 \quad 2017 \quad 2018 \quad 2019$

$\begin{array}{llllll}\text { Minimum LCR Requirement } & 60 \% & 70 \% & 80 \% & 90 \% & 100 \%\end{array}$

Source: Bank for International Settlements, 2013

The actual assets that are considered to be of a high quality and easily converted to cash with little or no change in value are categorized as Level 1 and Level 2 assets. Level 1 assets are cash, central bank reserves, and sovereign debt that qualifies for a weighted risk of $0 \%$ under the credit risk standards of Basel II. Level 2 assets are sovereign debts that qualify for a weighted risk of $20 \%$ under Basel III, as well as corporate bonds and covered bonds that have a minimum of an AA- credit rating. In order to determine the total value of high-quality liquid assets for the liquidity risk, at least $60 \%$ of a bank's assets that are considered to be high-quality liquid assets must be Level 1 assets, while no more than $40 \%$ of the assets can be Level 2 assets (AFME, 2014).

\section{Research methodology}

In order to test the liquidity coverage ratios of Canadian banks using the Basel III methodology, information would be needed regarding the amount of Level 1 and Level 2 assets held by the banks. Unfortunately, such information is currently considered to be confidential, and will not be publicly available until after January 2015, which is the data 
of the requirement to comply with the Basel III liquidity coverage ratio requirement. In order to overcome the inability to obtain the specific data that Canadian banks will have to use in order to show compliance with Basel III requirements, the standard calculation of the quick ratio. The use of the quick ratio to determine the liquidity coverage of the banks in this study is appropriate considering that the liquidity coverage ratio created under Basel III actual builds upon the liquidity ratios that are traditionally used in business (Bank for International Settlements, 2013). Furthermore, the quick ratio is a measure that is widely used in business to measure a company's short-term liquidity. The formula for the quick ratio that is used as the substitute for the liquidity coverage ratio for this investigation was carried out by using the liquid assets listed on the balance sheets of the Canadian banks included in this study.

Where:

$$
L R=\frac{L A}{L B}
$$

$$
\begin{array}{ll}
\text { LR }= & \text { Liquidity Ratio } \\
\text { LA }= & \text { Liquid Assets Listed on Balance Sheet } \\
\text { LB }= & \text { Liabilities Listed on Balance Sheet }
\end{array}
$$

While all liquid assets were used in the calculation, the liquidity coverage ratios that are reported in this study are likely close to the actual liquidity coverage ratios that will be calculated using the Level 1 and Level 2 requirements of Basel III. In addition, this method of determining the liquidity coverage ratios of Canadian banks is appropriate to draw conclusions about the readiness of the banks to meet the actual Basel III regulations beginning in 2015 when the initial requirement is a liquidity coverage ratio of only $60 \%$.

\subsection{Data}

The data for this study was drawn from the balance sheets of six major Canadian banks. The Canadian banks that were included in the study were Bank of Montreal (BMO), Bank of Nova Scotia (Scotiabank), Canadian Imperial Bank of Commerce (CIBC), National Bank, Royal Bank of Canada (RBC), and Toronto-Dominion Bank (TD). These six banks are the largest banks in Canada, and are often referred to in Canada as "the Big Six". Furthermore, the country's federal regulator designated these six banks in 2013 as being "too big to fail", as they account for more than $90 \%$ of the total banking assets in the country (The Canadian Press, 2013). The liquid assets and liabilities for each of the banks were gathered for the period from 2009 to 2013. The reason for using this period was that 2009 was the first full year after the financial crisis began; using data from 2009 to 2013 allowed for the ability to examine the trend in the changes in liquidity coverage for the banks in the aftermath of the financial crisis.

\subsection{Data analysis}

The analysis of the data consisted for calculating the liquidity ratios for the banks in this study for each of the years from 2009 to 2013 in order to determine if they are in compliance with the Basel III requirements that take effect in 2015 based on the data from 2013. However, beyond simply examining the liquidity coverage ratios calculated for the banks in this study using the data from 2013, the trends in changes in liquidity coverage ratios were also examined. It is important to note that the examination of the data is focused on each individual bank, as opposed to the six banks in this study as a group. Higher-level statistical tests could have been performed using the data from all of the banks included in the study. The decision was made to avoid performing higher-level statistical tests on the combined data from all of the banks. The reason for this is that under Basel III, each bank must individually meet the liquidity coverage ratio requirements. While the banks in a particular country may have an overall level of meeting the Basel III requirements that is high, any individual bank can be in non-compliance with the liquidity requirements. Therefore, we examine Canadian banks individually.

\section{Analysis and findings}

Table 2 shows the liquid assets for each of the six banks individually, as well as the overall level of liquidity for all of the banks from 2009 through 2013. The data show that from the period of 2009 through 2013, each of the six banks raised the value of their liquid assets. For example, BMO increased the value of its liquid assets from about $\$ 268$ million in 2009 to about $\$ 488$ million in 2013, while CIBC increased the value of its liquid assets from about $\$ 193$ million to about \$229 million. Of all of the banks in the sample, CIBC seemed to have the lowest level of increase in liquid assets. 
Table 2. Liquid assets of Canadian banks (in Canadian dollars)

\begin{tabular}{ccccccc}
\hline & $\begin{array}{c}\text { Bank of } \\
\text { Montreal }\end{array}$ & Scotiabank & $\begin{array}{c}\text { Canadian } \\
\text { Imperial } \\
\text { Bank of } \\
\text { Commerce }\end{array}$ & $\begin{array}{c}\text { National } \\
\text { Bank }\end{array}$ & $\begin{array}{c}\text { Royal Bank } \\
\text { of Canada }\end{array}$ & $\begin{array}{c}\text { Toronto-Dominion } \\
\text { Bank }\end{array}$ \\
\hline 2009 & $268,162,144$ & $341,210,035$ & $192,874,351$ & $96,463,444$ & $397,643,278$ & $364,754,734$ \\
2010 & $285,474,347$ & $353,016,357$ & $204,329,914$ & $107,458,389$ & $445,785,633$ & $414,752,116$ \\
2011 & $433,829,459$ & $452,233,154$ & $224,723,711$ & $144,045,276$ & $540,680,652$ & $591,919,577$ \\
2012 & $463,371,160$ & $506,368,511$ & $215,472,792$ & $159,452,300$ & $573,907,001$ & $631,724,867$ \\
2013 & $488,147,287$ & $551,105,146$ & $228,765,133$ & $169,352,869$ & $626,241,370$ & $680,158,608$ \\
\hline
\end{tabular}

Source: Office of the Superintendent of Financial Institutions (2014)

Table 3 shows the percentage increase in the liquid assets of each of the six banks in the study from 2009 to 2013 . The table shows that CIBC did have the lowest increase in the value of liquid assets of the six banks with an increase in liquid assets of just 18.6\%. In comparison, BMO increased its liquid assets by $82 \%$ from 2009 to 2013, while TD actually achieved an $86 \%$ increase in the value of its liquid assets during that period. Interestingly, CIBC was the only bank of the six banks in this study that experienced an increase in liquid asset of less than $50 \% \mathrm{~s}$ from 2009 to 2013.

Table 3. Percentage increase in liquid assets from 2009 to 2013

\begin{tabular}{cccccc}
\hline Bank of & Scotiabank & $\begin{array}{c}\text { Canadian } \\
\text { Imperial } \\
\text { Bank of } \\
\text { Commerce }\end{array}$ & $\begin{array}{c}\text { National } \\
\text { Bank }\end{array}$ & $\begin{array}{c}\text { Royal Bank } \\
\text { of Canada }\end{array}$ & $\begin{array}{c}\text { Toronto-Dominion } \\
\text { Bank }\end{array}$ \\
\hline $82.03 \%$ & $61.51 \%$ & $18.61 \%$ & $75.56 \%$ & $57.49 \%$ & $86.47 \%$ \\
\hline
\end{tabular}

Table 4 shows the liabilities of each of the six banks in this study from 2009 to 2013 . The data show that all of the banks in the study experienced increases in liabilities in the five years following the financial crisis. However, this is not surprising given that the costs of operations likely increased as a result of normal increases in costs and inflation. In addition, all of the banks in this study experienced increases in liquid assets, so the increases in liabilities does not necessarily mean that the banks have a liquidity problem simply because liabilities increased during the same period.

Table 4. Liabilities of Canadian Banks (in Canadian Dollars)

\begin{tabular}{ccccccc}
\hline & $\begin{array}{c}\text { Bank of } \\
\text { Montreal }\end{array}$ & Scotiabank & $\begin{array}{c}\text { Canadian } \\
\text { Imperial } \\
\text { Bank of } \\
\text { Commerce }\end{array}$ & $\begin{array}{c}\text { National } \\
\text { Bank }\end{array}$ & $\begin{array}{c}\text { Royal Bank } \\
\text { of Canada }\end{array}$ & $\begin{array}{c}\text { Toronto-Dominion } \\
\text { Bank }\end{array}$ \\
\hline 2009 & $368,261,053$ & $471,743,402$ & $321,669,175$ & $125,663,746$ & $613,183,006$ & $518,500,086$ \\
2010 & $389,760,092$ & $499,025,518$ & $336,250,377$ & $138,093,597$ & $687,255,874$ & $577,242,274$ \\
2011 & $449,299,762$ & $542,496,160$ & $336,358,850$ & $148,960,804$ & $709,994,509$ & $639,507,875$ \\
2012 & $495,359,453$ & $626,665,243$ & $376,347,855$ & $169,662,425$ & $779,071,789$ & $762,405,897$ \\
2013 & $505,817,696$ & $697,236,637$ & $379,960,670$ & $179,042,760$ & $810,484,048$ & $810,560,140$ \\
\hline
\end{tabular}

Source: Office of the Superintendent of Financial Institutions (2014)

Table 5 shows the percentage increase in the liabilities of the Canadian banks in this study from 2009 to 2013 . CIBC has the lowest percentage increase in liabilities of the six banks in the study from 2009 to 2013, at 18\%. TD had the largest overall percentage increase in liabilities from 2009 to 2013, at 56\%. TD was the only bank in the sample that had an overall increase in liabilities larger than $50 \%$ in the five years after the financial crisis 
Table 5. Percent change in liquid assets from 2009 to 2013

\begin{tabular}{|c|c|c|c|c|c|}
\hline $\begin{array}{l}\text { Bank of } \\
\text { Montreal }\end{array}$ & Scotiabank & $\begin{array}{c}\text { Canadian } \\
\text { Imperial } \\
\text { Bank of } \\
\text { Commerce }\end{array}$ & $\begin{array}{l}\text { National } \\
\text { Bank }\end{array}$ & $\begin{array}{c}\text { Royal Bank } \\
\text { of Canada }\end{array}$ & $\begin{array}{c}\text { Toronto-Dominion } \\
\text { Bank }\end{array}$ \\
\hline $37.35 \%$ & $47.80 \%$ & $18.12 \%$ & $42.48 \%$ & $32.18 \%$ & $56.33 \%$ \\
\hline
\end{tabular}

Figure 1 shows the overall percentage increases in liquid assets and liabilities for each of the six banks in the study. Five of the six banks in the study experienced increases in liquid assets in the five years following the financial crisis that were larger than the increases in liabilities that occurred. CIBC, however, had about the same level of increase for both its liquid assets and its liabilities, which was about $18 \%$. This could be problematic for CIBC as it suggests that the bank may have had the same liquidity level in 2013 as it had in 2009. If CIBC's liquidity level was low in 2009, then its liquidity level likely remained low in 2013.

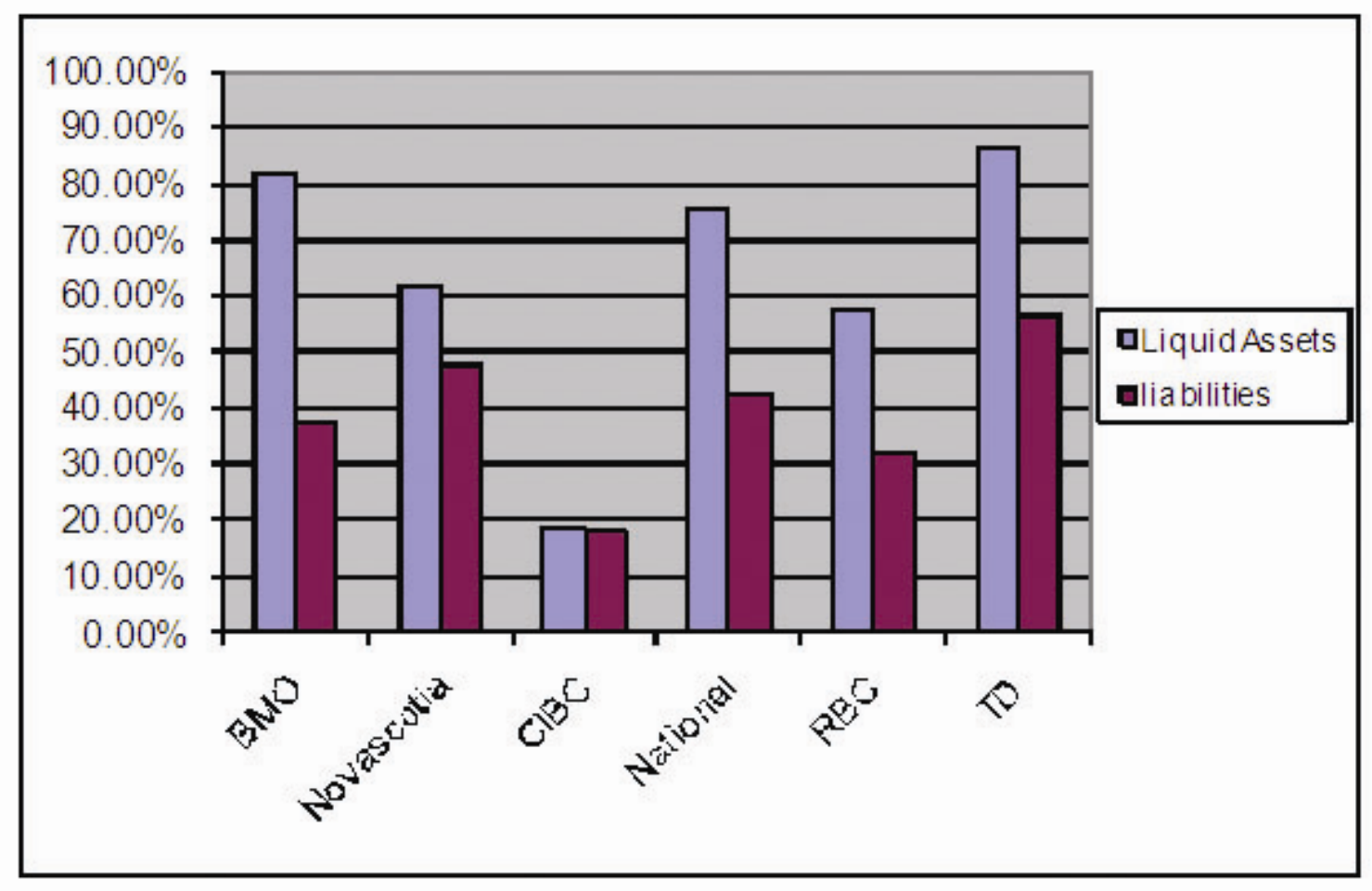

Figure 1. Comparison of change in liquid assets and liabilities from 2009 to 2013

Table 6 shows the liquidity coverage ratios for each of the banks for each year from 2009 through 2013 . The table shows that each of the six banks in this study did increase their liquidity coverage ratios in the five years following the financial crisis. Perhaps more importantly with regards to the implementation of Basel III requirements in 2015, five of the six banks in the study had liquidity coverage ratios in 2013 that were well above the $60 \%$ liquidity coverage ratio that will be required in 2015. BMO and National were prepared to meet the Basel III liquidity coverage ratio requirement for 2018, as they had liquidity coverage ratios in 2013 of $96.51 \%$ and $94.59 \%$, respectively. TD was prepared to meet the 2018 liquidity coverage ratio requirement of $80 \%$ in 2013 with a liquidity coverage ratio of $83.91 \%$. Scotiabank and $\mathrm{RBC}$ were able to meet the 2016 Basel III liquidity coverage ratio requirement of $70 \%$, as they had liquidity coverage ratios in 2013 of $79.04 \%$ and $77.27 \%$, respectively. 
Table 6. Liquidity coverage ratio of Canadian banks

\begin{tabular}{ccccccc}
\hline & $\begin{array}{c}\text { Bank of } \\
\text { Montreal }\end{array}$ & Scotiabank & $\begin{array}{c}\text { Canadian } \\
\text { Imperial } \\
\text { Bank of } \\
\text { Commerce }\end{array}$ & $\begin{array}{c}\text { National } \\
\text { Bank }\end{array}$ & $\begin{array}{c}\text { Royal BankToronto-Dominion } \\
\text { of Canada }\end{array}$ & Bank \\
\hline 2009 & $72.82 \%$ & $72.33 \%$ & $59.96 \%$ & $76.76 \%$ & $64.85 \%$ & $70.35 \%$ \\
2010 & $73.24 \%$ & $70.74 \%$ & $60.77 \%$ & $77.82 \%$ & $64.86 \%$ & $71.85 \%$ \\
2011 & $96.56 \%$ & $83.36 \%$ & $66.81 \%$ & $96.70 \%$ & $76.15 \%$ & $92.56 \%$ \\
2012 & $93.54 \%$ & $80.80 \%$ & $57.25 \%$ & $93.98 \%$ & $73.67 \%$ & $82.86 \%$ \\
2013 & $96.51 \%$ & $79.04 \%$ & $60.21 \%$ & $94.59 \%$ & $77.27 \%$ & $83.91 \%$ \\
\hline
\end{tabular}

For the five banks that have been discussed thus far - BMO, Scotiabank, National Bank, RBC, and TD - it seems appropriate to conclude that they are ready to meet the Basel III liquidity coverage ratio requirements that will take effect in 2015. In 2013, each of these five banks had liquidity coverage ratios that would have allowed them to meet at least the 2016 requirement of a $70 \%$ liquidity coverage ratio. Even more, BMO and National Bank were nearly able to meet the full 2019 Basel III requirement of $100 \%$ liquidity coverage ratios, as those two banks had liquidity coverage ratios in 2013 that were above $90 \%$.

While the ability to meet specific liquidity coverage ratios in a single year is important, it is also necessary to examine the trends in the liquidity coverage ratios of those five banks over the course of the five years following the financial crisis. Each of the five banks did experience a slight decline in their liquidity coverage ratios from 2011 to 2012. However, BMO, National Bank, RBC, and TD did increase their liquidity coverage ratios from 2012 to 2013. Scotiabank did not increase its liquidity coverage ratio from 2012 to 2013. Instead, Scotiabank's liquidity coverage ratio declined from $83.36 \%$ in 2011 to $80.80 \%$ in 2012 , followed by a further decrease to $79.04 \%$ in 2013 . While Scotiabank was well ahead of the 2015 Basel III liquidity coverage ratio requirement in 2013, the bank's leaders may want to closely watch its liquid assets and liabilities in order to ensure that further declines that could harm its ability to meet the 2016 liquidity coverage ratio requirement do not occur.

The one bank in the sample that has not yet been discussed in terms of its liquidity coverage ratio is CIBC. Of all six banks, CIBC had the lowest liquidity coverage ratio from 2009 through 2013. More importantly with regards to the Basel III requirements, CIBC had a liquidity coverage ratio in 2013 of $60.21 \%$. In 2013, CIBC was barely able to meet the 2015 liquidity coverage ratio requirement of $60 \%$. The bank's liquidity ratio did increase from $57.25 \%$ in 2012 to $60.21 \%$ in 2013, but the risk remains that even a very small decline in CIBC's liquidity coverage ratio would mean not being in compliance with Basel III requirements for 2015.

On a broader level, the other five banks in this study were able to meet the minimum Basel III requirements outlined for 2015 in 2009. In fact, BMO, Scotiabank, National Bank, and TD could have met the 2016 Basel III liquidity coverage ratio requirement of $70 \%$ in 2009 . CIBC was not able to meet the 2015 liquidity coverage ratio requirement in 2009, and was not in compliance with that requirement in 2012. In the five years following the financial crisis, $\mathrm{CIBC}$ has moved from being in compliance to not being in compliance with 2015 requirements, and only barely met those requirements in 2013.

Based on the data that have been analyzed, most of the large Canadian banks appear to be ready to meet the Basel III requirements that begin in 2015. Even if the banks experience some decline in their liquidity coverage ratios, they should be able to meet the 2015 requirements, as most are actually already able to meet the 2016 or 2017 requirements; the one exception to this, however, is CIBC, which is indeed a bank that deserves further attention and some concern on the part of investors, customers, and financial regulators about its readiness to meet Basel III liquidity coverage ratio requirements. The goal for both banks and regulators in Canada should be to ensure that banks have some sort of buffer, in order to be able meet the 2015 Basel III requirements.

\section{Discussion}

The results of this study would seem to be positive in terms of the ability of most of the major Canadian banks to meet Basel III liquidity coverage ratio requirements for 2015. However, it is useful to compare the readiness of the major Canadian banks in this study with Basel III requirements with their US and European counterparts. The data and studies regarding the ability of banks in Europe to fully comply with the liquidity coverage ratio requirements of Basel III seem to be in conflict. For example, the authors (Sutorova \& Teply, 2013) of the recent study regarding the impact of Basel III liquidity requirements on banks in Europe argued that many banks in the European Union were 
already complying with Basel III liquidity requirements. Other researchers, however, have argued that large European banks will likely have to reduce lending in order to reduce the liabilities on their balance sheets so that they will be in full compliance with Basel III (Allen, Kei, Chan, Milne \& Thomas, 2012). Furthermore, the European Banking Authority was reported to have indicated that at the end of 2012, the largest banks in Europe were nearly $\$ 100$ billion Canadian Dollars short of being able to meet the capital requirements of Basel III (CBC News, 2013).

In terms of the ability of banks in the US to meet the liquidity requirements of Basel III, a recent report found that 20 of the 26 largest banks in the US were able or would be able to meet those requirements (Weinberger, 2014). However, the report also stated that six of the largest banks in the US, namely State Street Corp., the Bank of New York Mellon Corp, Comerica, Inc., U.S. Bancorp, Northern Trust Corp., and M\&T Bank, were not prepared to meet the liquidity requirements of Basel III as of the first quarter of 2014.

In comparison to banks in Europe and the US, it would seem that the largest banks in Canada are as prepared or even better prepared to meet Basel III requirements. The largest banks in the United States and Canada seem to generally have the same level of readiness to meet Basel III. Unfortunately, Europe seems to be particularly problematic in terms of banks meeting Basel III liquidity requirements because of the vast differences in lending practices and the amount of capital held by banks in different countries across the continent (Howarth \& Quaglia, 2013). Unlike the US or Canada, the vastly different economic conditions and structures of the many countries that comprise the European Union may mean that overall, European banks are indeed less prepared to meet Basel III requirements.

\section{Conclusion}

The purpose of this study has been to analyze and test the current Canadian bank liquidity coverage ratio in order to draw conclusions about the readiness of Canadian banks to meet Basel III regulations. From a broad perspective, the data that has been analyzed allows for the conclusion that most large Canadian banks are ready to meet the Basel III liquidity coverage ratio requirements. However, the results of the data analysis conducted in this study showed that not all large Canadian banks are on solid enough ground to be able to meet the Basel III liquidity coverage ratio requirements. Specifically, CIBC had a liquidity coverage ratio of $60 \%$ in 2013 , but that was actually an improvement from 2012, when the bank had a liquidity coverage ratio of $57.25 \%$. The bank's data show that CIBC may not be able to meet and maintain compliance with the 2015 requirement of a liquidity coverage ratio of $60 \%$, and certainly has the risk of not meeting the 2017 Basel III requirement of a 70\% liquidity coverage ratio.

While the overall data indicate that most large Canadian banks are indeed ready to meet the Basel III requirements that take effect in 2015, regulators in Canada should avoid being blindsided by the broad data and examine the data from each bank in the country. Basel III requirements are implemented for each bank, not for an entire nation. This means that while most Canadian banks may be well prepared for demonstrating compliance with Basel III, some banks may not be ready to demonstrate compliance. It would be easy for financial regulators in Canada to be happy with the overall findings of this study, to the point of ignoring the fact that one of the country's major banks, CIBC, may not be able to comply with Basel III requirements.

Another issue that must be considered for banks that are only slightly prepared to meet the 2015 Basel III liquidity requirements is that liquidity coverage ratio requirements increase by $10 \%$ each year until 2019 . For banks that are only slightly prepared to meet the 2015 requirements, the question must be raised as to whether they can realistically increase their liquidity coverage ratios by $10 \%$ in a single year. Unfortunately, some type of government intervention might be necessary to ensure that banks that are already struggling will be able to achieve full compliance with Basel III in 2015, and can achieve compliance with the increasing liquidity requirements that will occur until 2019.

The primary limitation of this study is the way in which the liquidity coverage ratios of the banks that were investigated were calculated. The argument could be made that the results of this study may not accurately reflect the actual liquidity coverage ratios of the banks that have been examined, as it was not possible to determine the actual liquid assets that would qualify under Basel III requirements. While this might affect the specific liquidity coverage ratios of the banks that were examined, it seems unlikely that this would cause a bank that was deemed to have a high liquidity coverage ratio to actually show an inability to comply with Basel III in 2015. The one exception to this might be CIBC. Once CIBC's actual liquid assets that qualify as highly liquid and of a high-quality under Basel III are examined, the bank may demonstrate further problems achieving and maintaining Basel III compliance. In this regard, rather than focusing on the finding that CIBC can comply with the 2015 Basel III liquidity requirement, regulators need to focus on the decisions of CIBC and all banks as to how they plan to achieve and maintain Basel III compliance on a permanent basis. 
Considering that Basel III requirements will be implemented in the very near future, the recommendation for future research is to investigate the characteristics and conditions of those banks that are found to not be in compliance with Basel III liquidity coverage ratio requirements once they take affect in 2015. Once the requirements take full effect, the role for researchers will need to be one of helping to identify why certain banks are not meeting requirements, and what is needed for those banks to come into compliance with Basel III. Even in a country such as Canada, the potential for one of the big six banks to not be in compliance with Basel III presents an important opportunity to examine why the bank was not ready before compliance was required, and to highlight the internal actions that may have resulted in a lack of compliance if such an event were to occur.

\section{References}

Acharya, V., \& Schaefer, S. (2006). Liquidity risk and correlation risk: Implications for risk management. London, UK London Business School.

AFME. (2014). Liquidity Coverage Ratio. www.afme.eu/WorkArea/DownloadAsset.aspx?id=126

Allen, B., Chan, K. K., Milne, A., \& Thomas, S. (2012). Basel III: Is the cure worse than the disease? International Review of Financial Analysis, 25, 159-166. http://dx.doi.org/10.1016/j.irfa.2012.08.004

Asongu, S. A. (2013). Post-crisis bank liquidity risk management disclosure. Qualitative Research in Financial Markets, 5(1), 65-84. http://dx.doi.org/10.1108/17554171311308968

Avadanei, A. (2013). The impact of new regulation on four European banking systems. A Basel III approach. The USV Annals of Economics and Public Administration, 13(2), 193-199.

Bank for International Settlements (2013). Basel III: The Liquidity Coverage Ratio and Liquidity Risk Monitoring Tools.

Bech, M., \& Keister, T. (2012). On the liquidity coverage ratio and monetary policy implementation. BIS Quarterly Review, December 2012, 49-61.

Bergevin, P., Calmès, C., \& Théoret, R. (2013). Time-varying leverage and Basel III: A look at Canadian evidence. International Advances in Economic Research, 19(3), 233-247. http://dx.doi.org/10.1007/s11294-013-9411-6

Bessis, J. (2011). Liquidity risk: A risk left to be tamed. Journal of Risk Management in Financial Institutions, 4(2), $108-111$.

Brunnermeier, M. K., \& Pedersen, L. H. (2009). Market liquidity and funding liquidity. Review of Financial studies, 22(6), 2201-2238. http://dx.doi.org/10.1093/rfs/hhn098

CBC News. (2013). EU banks $\$ 98$ billion short of meeting Basel III capital rules. Retrieved from http://www.cbc.ca/news/business/eu-banks-98b-short-of-meeting-basel-iii-capital-rules-1.1868191.

Clerc, L. (2008). Liquidity in a time of financial turbulences. Financial Stability Review, 11, I-IV.

Diamond, D. W., \& Rajan, R. G. (2001). Liquidity risk, liquidity creation and financial fragility: A theory of banking. Journal of Political Economy 109(2). http://dx.doi.org/10.1086/319552

Gatev, E., Schuermann, T., \& Strahan, P. (2007). How do banks manage liquidity risk? Evidence from the equity and deposit markets in the Fall of 1998. In The risks of financial institutions (pp. 105-132). Chicago: University of Chicago Press. http://dx.doi.org/10.7208/chicago/9780226092980.003.0004

Gomes, T., \& Khan, N. (2011). Strengthening bank management of liquidity risk: The Basel III liquidity standards. Bank of Canada Financial System Review, 5, 35-42.

Gromova-Schneider, A., \& Niziolek, C. (2011). The road to Basel III - Quantitative impact study, the Basel III framework and implementation in the EU. Financial Stability Report, 21, 58-61.

Hartlage, A. W. (2012). The Basel III liquidity coverage ratio and financial stability. Michigan Law Review, 111(3), 453-484.

Howarth, D., \& Quaglia, L. (2013). Banking on stability: The political economy of new capital requirements in the European Union. Journal of European Integration, 35(3), 333-346. http://dx.doi.org/10.1080/07036337.2013.774780

Ismal, R. (2010). Managing banking liquidity risk in the current economic conditions: A conceptual framework. Journal of Management \& Public Policy, 1(2), 1-27. 
Jasevičienė, F., Jasienė, M., Krivkienė, G., \& Martinavičius, J. (2012). Bank liquidity risk: Analysis and estimates. Business, Management and Education, 2, 186-204. http://dx.doi.org/10.3846/bme.2012.14

Jordan, A., Branch, S., McQuay, A., Cooper, Y., \& Smith, L. (2013). An analysis of bank liquidity in the Bahamas. Journal of Business, Finance \& Economics in Emerging Economies, 8(2), 55-72.

Maria, B., Andrei, M., Catalin, S., \& Anamaria, P. (2013). Romanian banks liquidity management. Romania, l(1), 1053-1061.

Nucu, A. E. (2011). The challenges of Basel III for Romanian banking system. Theoretical and Applied Economics, 12(12), 59-70.

Office of the Superintendent of Financial Institutions. (2014). Financial data for banks. Retrieved from: http://www.osfi-bsif.gc.ca/Eng/wt-ow/Pages/FINDAT.aspx

Ratnovski, L. (2013). Liquidity and transparency in bank risk management. Journal of Financial Intermediation, 22(3), 422-439. http://dx.doi.org/10.1016/j.jfi.2013.01.002

Rafea, F., \& Rad, A. (2014). Measurement of liquidity risk in Keshavarzi Bank (with value at risk approach). International Journal of Academic Research in Business and Social Sciences, 4(2), 74-87. $\mathrm{http}: / / \mathrm{dx}$.doi.org/10.6007/IJARBSS/v4-i2/596

Ramona, T. (2013). Comparative analysis of the bank's capital adequacy according to the Basel agreement. The Annals Of The University Of Oradea, 1(1), 1125-1132.

Sohaimi, A. N. A. (2013). Liquidity Risk and Performance of Banking System in Malaysia. Available at SSRN 2271427.

Sutorova, B., \& Teply, P. (2013). The impact of Basel III on lending rates of EU banks. Czech Journal of Economics and Finance (Finance a uver), 63(3), 226.243.

The Canadian Press (2013). Canada's big 6 banks are too big to fail, regulator says. Retrieved from http://www.cbc.ca/news/business/canada-s-big-6-banks-are-too-big-to-fail-regulator-says-1.1334560.

van den End, J. W. (2012). Liquidity stress-tester: Do Basel III and unconventional monetary policy work? Applied Financial Economics, 22(15), 1233-1257. http://dx.doi.org/10.1080/09603107.2011.646065

Vasile, D. E. D. U., \& Nitscu, D. C. (2012). Basel III - Between global thinking and local acting. Theoretical and Applied Economics, 18(6), 5-12.

Vogiazas, S., \& Alexiou, C. (2013). Liquidity and the business cycle: Empirical evidence from the Greek banking sector. Ekonomski anali, 58(199), 109-125. http://dx.doi.org/10.2298/EKA1399109V

Weinberger, E. (2014). Most banks ready for fed's liquidity rules, report says. Retrieved from http://www.law360.com/articles/556230/most-banks-ready-for-fed-s-liquidity-rules-report-says.

Wu, D., \& Hong, H. (2012). Liquidity risk, market valuation, and bank failures. Market Valuation, and Bank Failures, 36, 2260-2671. 